Role of agricultural engineering in environmental and sustainable development for the valley and delta areas: $1674-1687$

\title{
DEVELOPMENT AND EVALUATION OF A LOCAL OIL SEEDEXPLIER TO IMPROVE THE EXTRACTION EFFICIENCY
}

\author{
${ }^{1}$ Helmy. M., ${ }^{2}$ T Fouda ${ }^{3}$ A .Derbala. ${ }^{4}$ O.Kaddour ${ }^{5}$ N .Yassa
}

\section{ABSTRACT}

In small-scale industries for dyeing and in medicines as antiinflammatory substance. Seeds have been used as insecticide and oil extraction for fuel, soap and varnish production. Seed cake has been used as fertilizer, as solid fuel, or in biogas production. Non toxic varieties detoxified seed cake has been used as feed for animal.

An local oil extraction machine used to extract different varieties of oil seeds developed and evaluated to increase the extraction efficiency, and find the solution for the most problem of all oil press extraction machines that the high percentage of oil in cotton seed cake by use the press screw pitch of double flight, number of blades of 18 blades, development the machine head to control the clearance between machine head and press screw of 1, 1.5 . 2 and 2.5mm, and studying the effect of press screw speed of 30, 60, 90 and 120 rpm on machine efficiency and final product quality .The optimum parameters and condition of machine were $32.43 \mathrm{~kg} / \mathrm{h}$ machine productivity, $88.10 \mathrm{~kW} . \mathrm{h} /$ ton energy requirement, 63.905 extraction efficiency, $11.08 \%$ oil extracted percentage, $6.51 \%$ oil percentage in cake, by using double flight press screw, clearance of $1.5 \mathrm{~mm}$, screw speed of $90 \mathrm{rpm}$ and 18 blades number the obtained results were very important for oil extraction industries that use the oil press method for oil extraction.

\section{INTRODUCTION}

Total Egyptian oilseed production declined in 2009/2010 by about 11 percent from the 2008/2009 level. However, total oilseed production is forecast to increase by 37 percent in 2010/2011 due to the expected increase in cotton production.Cotton is the major oilseed grown in Egypt.

\footnotetext{
${ }^{\text {I} P r o f e s s o r ~ o f ~ A g r i c u l t u r e ~ E n g i n e e r i n g ~ K a f e r ~ E l ~ S h e a k ~ U n i v e r s i t y ~}$

${ }^{2}$ Professor of Agriculture Engineering Tanta University

${ }^{3}$ Associate professor of Agriculture Engineering Tanta University

${ }^{4}$ Sinor researcher of Agriculture Engineering Research Institute (AEnRI)

${ }^{5}$ Assistant Researcher of Agriculture Economical institute
} 
It is produced primarily for fiber, with oil and meal production being of secondary importance. The government sells cottonseed to farmers, at $3.60 \mathrm{LE} / \mathrm{kgEgypt}$ 's annual oilseed crushing capacity is currently estimated at 1.8 million tons. About 60 percent of Egypt's crushing capacity is owned by public sector companies. ( Central Agency of Public Mobilization and Statistics 2010) . Oil recovery from oil-seed is by one of four methods namely, the aqueous (or traditional) method, hydraulicpressing, screw pressing and solvent extraction. In the traditional method, the seed is ground into a paste, the paste is heated in boiling water and the mixture stirredperiodically while it is being heated until the oil is seen floating on the meal-water mixture. The mixture is then allowed to cool off during which time oil is scooped off the top of the mixture, (UNIFEM 1987).

Herz,( 1997)reported that oil can be extracted mechanically with a ram press, an expeller or even a wooden mortar and pestle, a traditional method that originated in India. Presses range from small, hand-driven models that an individual can build to power-driven commercial presses. The ram press uses a piston inside a cage to crush the seed and force out the oil. Expellers have a rotating screw inside a horizontal cylinder that is capped at one end. The screw forces the seeds or nuts through the cylinder with gradually increasing pressure. The seed is heated by friction and electricheaters or a combination of the two. Once the cap is removed, the oil escapes from the cylinder through small holes or slots and the press cake, or meal, emerges from the end of the cylinder. Both the pressure and temperature can be adjusted for different kinds of feedstock

Oyinlola et al (2003) reported that ,a model screw press was designed and fabricated. In the design of the screw press, the size of the screw material, the optimum shaft length for a given screw pitch, appropriate shaft speed, the tapering angle of the conical shaft, the maximum shaft, diameter and the inside diameter of the enclosing barrel were determined. A shaft speed of not more than $90 \mathrm{rpm}$ was found to be suitable for working the screw press while the clearance between the shaft and the barrel was $3 \mathrm{~mm}$. Quality evaluation of the product showed that the acid 
value, the saponification number and the peroxide value of the oil obtained from roasted peanut were lower than that obtained from fresh peanut, implying that oil expressed from roasted peanut is of better quality to the oil.

Mpagalile et al.(2005)designed a simple pressing mechanism was carried out using avertical screw that was rotated by a gear system through a 12VDC motor connected to the solar PV panels. The press cylinder (Fig. 2) was made of a perforated $5 \mathrm{~mm}$ thick mild steel cylinder with $10 \mathrm{~mm}$ holes placed $5 \mathrm{~mm}$ apart along its circumference. The cylinder waslined with a $2 \mathrm{~mm}$ wire mesh on the inside. The frame was made up of four vertical solidmild steel rods of $50 \mathrm{~mm}$ diameters while the press base was made up of a200mm_600mm_12.7mm mild steel plate and was designed for better stability underpossible uneven surfaces in villages.An average specific energy of 36.55 and20.35 W. h/kg was recorded for peanuts and coconuts, respectively, after $12 \mathrm{~min}$ of pressing.

\section{The objective of this study were :}

(1) Development of a local oil seed extraction machine to improve the extraction efficiency.(2) Determine the optimum screw press pitch, and screw speed, number of blades, and the clearance between the screw end and machine head that affect on extraction efficiency.(3) Reducing the percentage of oil in produced cotton seed meal cake. (4) Reducing the power requirements of this type of machines.

\section{MATERIALS AND METHODS}

\section{Materials:}

The oil extraction machine manufactured in small workshop in ZagzagEl Sharkia, and evaluated in Agriculture engineering research institute (AEnRI) Giza. Cotton oil seeds harvested in season of 2009-2010 used in this study, the nutrient composition of standard cotton oil seed meals resulting from solvent or mechanical extraction showed in Table (1). 
Table (1): Nutrient composition of standard cotton oil seed meals resulting from solvent or mechanical extraction

\begin{tabular}{|c|c|c|c|c|c|c|c|c|c|}
\hline \multicolumn{10}{|c|}{$\begin{array}{l}\text { Nutrient composition of Cotton oilseed meals resulting from solvent or } \\
\text { mechanical extraction }\end{array}$} \\
\hline \multicolumn{10}{|c|}{ Dry matter basis } \\
\hline & $\begin{array}{c}\mathrm{DM} \\
\%\end{array}$ & $\begin{array}{c}\mathrm{CP} \\
\%\end{array}$ & $\begin{array}{c}\text { Fat, } \\
\%\end{array}$ & $\begin{array}{c}\text { TDN, } \\
\%\end{array}$ & $\begin{array}{l}\mathrm{NEm}, \\
\mathrm{Mcal} / \mathrm{lb}\end{array}$ & $\begin{array}{l}\mathrm{NEg}, \\
\mathrm{Mcal} / \mathrm{lb}\end{array}$ & $\begin{array}{c}\mathrm{ADF}, \\
\%\end{array}$ & $\mathrm{Ca}$ & $\begin{array}{l}\mathrm{P} \\
\%\end{array}$ \\
\hline $\begin{array}{l}\text { cotton seed } \\
\text { meal, } \\
\text { mechanical } \\
\text { extraction, }\end{array}$ & 92.6 & 36.9 & 14.1 & 88 & 1.09 & 0.77 & NG & 0.6 & 1.02 \\
\hline $\begin{array}{c}\text { Cotton- } \\
\text { meal, } \\
\text { solvent } \\
\text { extraction }\end{array}$ & 89 & 49 & 1.2 & 84 & 0.94 & 0.64 & NG & 0.33 & 0.71 \\
\hline
\end{tabular}

\section{Specification of a local developed extraction machine:}

The oil extraction machine consists of :

1- Machine base : Machine base made from U shape steel bars has width of $50 \mathrm{~mm}$, highest of $30 \mathrm{~mm}$, and thickness of $10 \mathrm{~mm}$, the base has dimension of $1060 \mathrm{~mm}$ length,350 mm width and130mm highest.(Fig 1)

2- $\quad$ Feeding hopper: The feeding hopped of cotton seed made from steel sheet has thickness of $1 \mathrm{~mm}$, and upper diameter of $140 \mathrm{~mm}$, And bottom diameter of $80 \mathrm{~mm}$, the highest of feeding hopper were 130mm..(Fig 1)

3- $\quad$ Extraction barrel : the extraction barrel has cylindrical shape has $370 \mathrm{~mm}$ length, $80 \mathrm{~mm}$ diameter and $2 \mathrm{~mm}$ thickness, the cylinder opening from the both sides the front end fixed with the extraction head, and the back end closed by bearing plate has diameter of $116 \mathrm{~mm}$, and thickness of $100 \mathrm{~mm}$, there are 8 holes has diameters of $12 \mathrm{~mm}$, for oil output..(Fig 1)

4- Extraction screw press: The extraction screw press, has length of $360 \mathrm{~mm}, 30 \mathrm{~mm}$ diameters , $40 \mathrm{~mm}$ diameters in bearings section, and 
$33.5 \mathrm{~mm}$ pitch .the screw teeth has width of $10 \mathrm{~mm}$, and teeth deeps of $12 \mathrm{~mm}$.(Fig 2)

5- Extraction head: Extraction head has conk shape the big diameter were $116 \mathrm{~mm}$, and the small were $95 \mathrm{~mm}$, (Fig3).

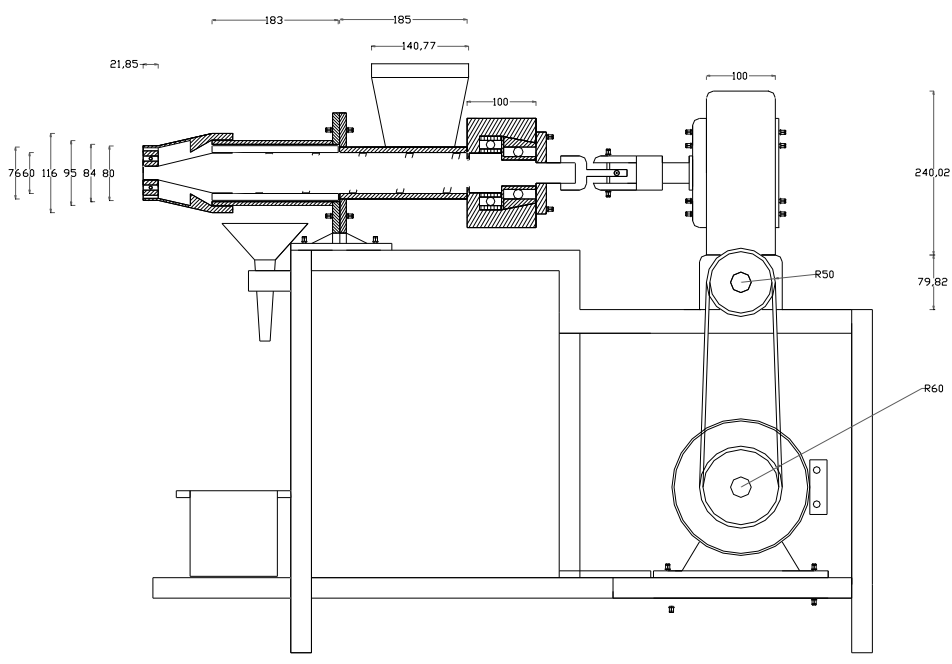

Fig(1): Elevation of oil extraction machine

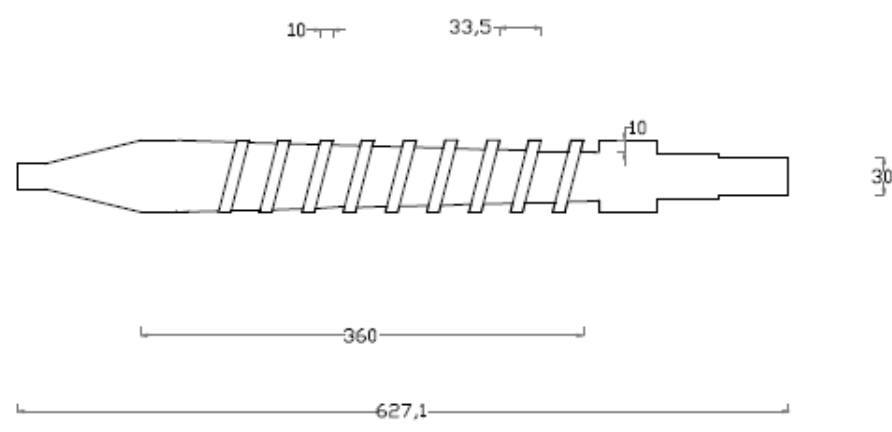

Fig(2): Extraction screw press 


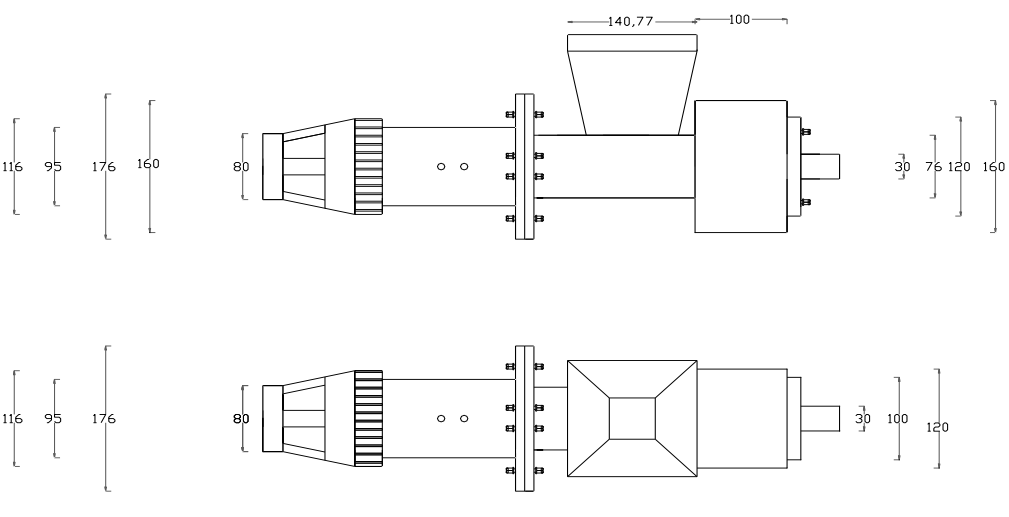

Fig(3): Extraction machine barrel and head

6- Power transmission and electric motors :The power transmitted from an electric $4 \mathrm{~kW}, 1400 \mathrm{rpm} 3$ vase . the electric motor shaft has pulley $120 \mathrm{~mm}$ in diameter, connected with the screw pulley has diameter of $100 \mathrm{~mm}$ by rubber belt $17 \mathrm{inch}$.

\section{Methods:}

An local oil extraction machine used to extract different varieties of oil seeds developed and evaluated to increase the extraction efficiency, by studying the effect off different operating parameters on machine efficiency and product quality such as:

1- Press screw pitch of double flight

2-Number of blades of 18 blades

3-Clearance between machine head and press screw of 1, 1.5, 2 and $2.5 \mathrm{~mm}$ 4-Screw speed of 30, 60, 90 and $120 \mathrm{rpm}$

\section{Evaluation of extruder efficiency and product quality Performance}

1- Extruder production rate was measured for each treatment by taking sample for $2 \mathrm{~min}$ after $10 \mathrm{~min}$. of extruder running at steady condition 2- Specific mechanical energy (SME), was calculated as the following relation:

$$
\text { Total consumed power, }(k W)=\frac{\sqrt{3} I V \eta \cos \theta}{1000}
$$


Where: I = Line current strength in amperes.

$\mathrm{V}=$ Potential difference (Voltage) being equal to $380 \mathrm{~V}$.

$\operatorname{Cos} \theta=$ Power factor (being equal to 0.84 ).

$\eta \quad=$ Mechanical efficiency assumed (90\%).

The energy requirement in $(\mathrm{kW} . \mathrm{h} / \mathrm{ton})$ : was calculated by the following equation:

$$
\text { Energyconsumed }=\frac{P}{Q}=k W . h / \text { ton }
$$

Where: $\mathrm{P}=$ The consumed power for mixing ration, $\mathrm{kW}$.

$\mathrm{Q}=$ Machinery line productivity, ton/h.

3- Extractionefficiency :was determined as per ASAE standards method DEC01(2000), at 3 replicates.

$$
\text { Efficiency }(\%)=\frac{W o}{W i} x 100
$$

Where:Wo :oil mass after extcation ( $\mathrm{g}$ ),

Wi: oil mass in $\operatorname{seed}(\mathrm{g})$

4- oil extracted percentage:

$$
\text { oil }-\operatorname{extracted}(\%)=\frac{W o}{W b} x 100
$$

Where:Wo :Oil extracted mass ( $\mathrm{g}$ ),

Wb: Total sample mass $(\mathrm{g})$

\section{5- Oil in cake percentage :}

$$
\text { oil }-\operatorname{cake}(\%)=\frac{W i-W o}{W i} x 100
$$

6- Product thickness: was determined by digital scale

\section{RESULTS AND DISCUSSION}

Evaluation of oil press performance and product quality was carried out under the following items:.

\section{1- Oil press Productivity:}

Productivity of oil extraction machine one of the most important aim for any industries witch affecting the final product cost.Data in Fig.( 4 ) indicated that the machine productivity increased from 19.61 to 24.25 , 27.70 and $30.01 \mathrm{~kg} \backslash \mathrm{h}$ using $1 \mathrm{~mm}$ clearance, from 24.10 to 28.98 , 32.43 and $34.74 \mathrm{~kg} / \mathrm{h}$ using 1.5 clearance, from 27.47 to 32.35 , 35.80and 
$38.11 \mathrm{~kg} \backslash \mathrm{h}$. using $2 \mathrm{~mm}$ clearance and from 32.93 to $37.81,41.26$ and $43.57 \mathrm{kglh}$. using $2.5 \mathrm{~mm}$ clearance under 18 number of blades and double flight screw.

The increase in machine productivity by increasing the screw speed from 30 to 60,90 and $120 \mathrm{rpm}$ could be due to the decrease in seeds retention time inside the expeller barrel, that increase the machine output in the time unit.

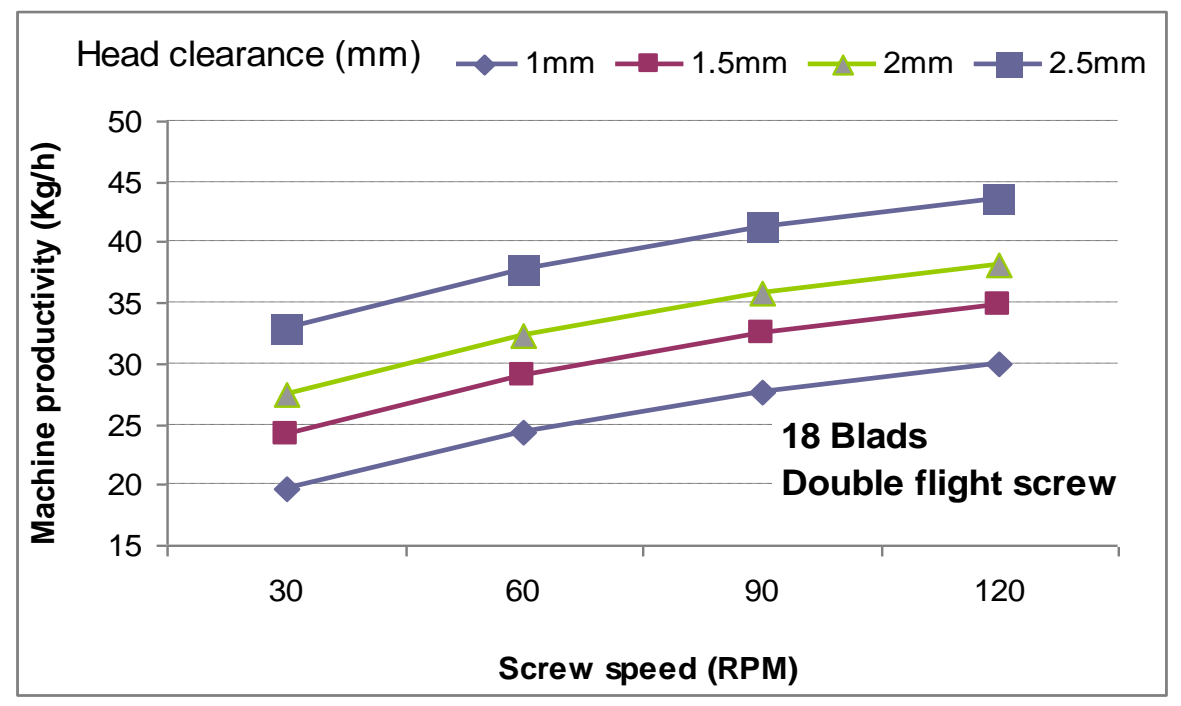

Fig(4): Effect of press screw speed and the clearance between the screw andmachine head on machine productivity

Data in Fig (4) showed that, expeller head the most important part in oil extraction machine witch controlling the machine productivity and extraction efficiency, it is indicated that increasing the clearance between the pressing screw and machine head from 1 to 1.5 , 2and 2.5 $\mathrm{mm}$ increased the machine productivity from19.61 3to 24.1, 27.47 and $32.93 \mathrm{~kg} \backslash \mathrm{h}$ at screw speed of $30 \mathrm{rpm}$, from . 24.25 to $28.98,32.35$ and $37.81 \mathrm{~kg} \mathrm{lh}$ at screw speed of $60 \mathrm{rpm}$, from 27.7 to $32.43,35.8$ and 41.26 $\mathrm{kg} \mathrm{lh}$ at screw speed of $90 \mathrm{rpm}$, and from 43.57 to $34.74,38.11$ and $30.01 \mathrm{~kg} \mathrm{lh}$ at screw speed of $120 \mathrm{rpm}$

The increase in machine productivity by increasing the head clearance from 1to 1.5, 2 and $2.5 \mathrm{~mm}$ could be due to the increase in machine opening area that decease the treatment consumed time. 


\section{2- Energy requirements :}

Data in Fig (5) indicated that increasing the screw speed from 30 to60,90 and 120 decreased the energy requirements from 139.618 to $118.436,106.555$ and $101.333 \mathrm{~kW} . h \mid t o n . u s i n g$ clearance of $1 \mathrm{~mm}$, from 109.6891 to $95.847,88.102$ and $84.819 \mathrm{~kW}$.h $\mid$ ton.using clearance of $1.5 \mathrm{~mm}$, from 93.338 to $83.405,77.182$ and $75.232 \mathrm{~kW} . h \mid$ ton.using clearance of $2 \mathrm{~mm}$ and from 75.146 to 63.751, 65.153 and $68.995 \mathrm{~kW}$.hlton.using clearance of $2.5 \mathrm{~mm}$

The decreased in energy requirement by increase the screw speed from $30,60,90$ and $120 \mathrm{rpm}$ could be due to the high increase in machine productivity with low increase in power consumed, that decrease the energy requirements.

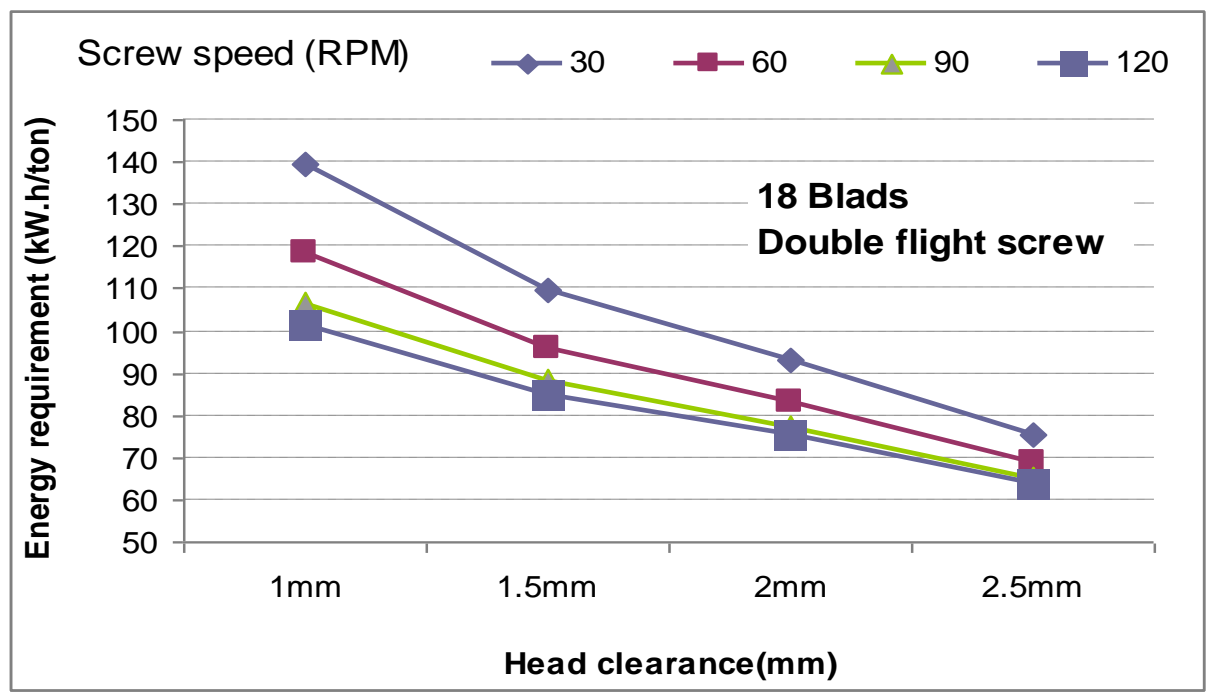

Fig(5 ): Effect of expeller screw speed, head clearance on energy requirements

While same Fig(5) showed that increased the head clearance from 1to $1.5,2$ and $2.5 \mathrm{~mm}$ deceased the energy requirements from 109.689 to $139.618,93.338$ and $75.146 \mathrm{~kW}$.h $\mid$ ton. using screw speed of 30rpm, from 118.436 to $95.847,83.405$ and $68.995 \mathrm{~kW}$.hlton. using screw speed of 60rpm, 106.555 to $88.102,65.153$ and $77.182 \mathrm{~kW}$.hlton. using screw speed of 90rpm and from 101.333 to $84.819,75.232$ and63.751kW.hlton. using screw speed of $120 \mathrm{rpm}$. The decreased in energy requirements by 
increase the machine head clearance from 1 to $1.5,2$ and $2.5 \mathrm{~mm}$ could be due to the increase in machine productivity and the decrease in power consumed by the decrease in motor load

\section{3- Extraction efficiency:}

Data in Fig (6) indicated that increasing the screw speed from 30 to60,90 and 120 decreased the extraction efficiency from 68.509 to 67.875 , 66.376 and $65.569 \%$ using clearance of $1 \mathrm{~mm}$, from 66.030 to 65.396 , 63.898 and $63.091 \%$ using clearance of $1.5 \mathrm{~mm}$, from 60.612 to 62.803 , 61.304 and $63.321 \%$ using clearance of $2 \mathrm{~mm}$ and from 57.039 to $59.229,57.731$ and $59.748 \%$.using clearance of $2.5 \mathrm{~mm}$.

The decreased in extraction efficiency by increase the screw speed from $30,60,90$ and $120 \mathrm{rpm}$ could be due to the decrease in treatment retention time by the high screw speed

On another hand, data in Fig (6) showed that increasing the clearance between the pressing screw and machine head from 1 to 1.5, 2and 2.5 $\mathrm{mm}$ decreasedextraction efficiency from68.509 to 66.030, 63.321and $59.748 \%$ using screw speed of $30 \mathrm{rpm}$, from 67.875 to $65.396,62.803$ and $59.229 \%$ using screw speed of $60 \mathrm{rpm}$, from 66.376 to 63.898 , 61.304and 57.731\%using screw speed of $90 \mathrm{rpm}$., from65.569 to 63.091, 60.612 and $57.039 \%$ using screw speed of $120 \mathrm{rpm}$

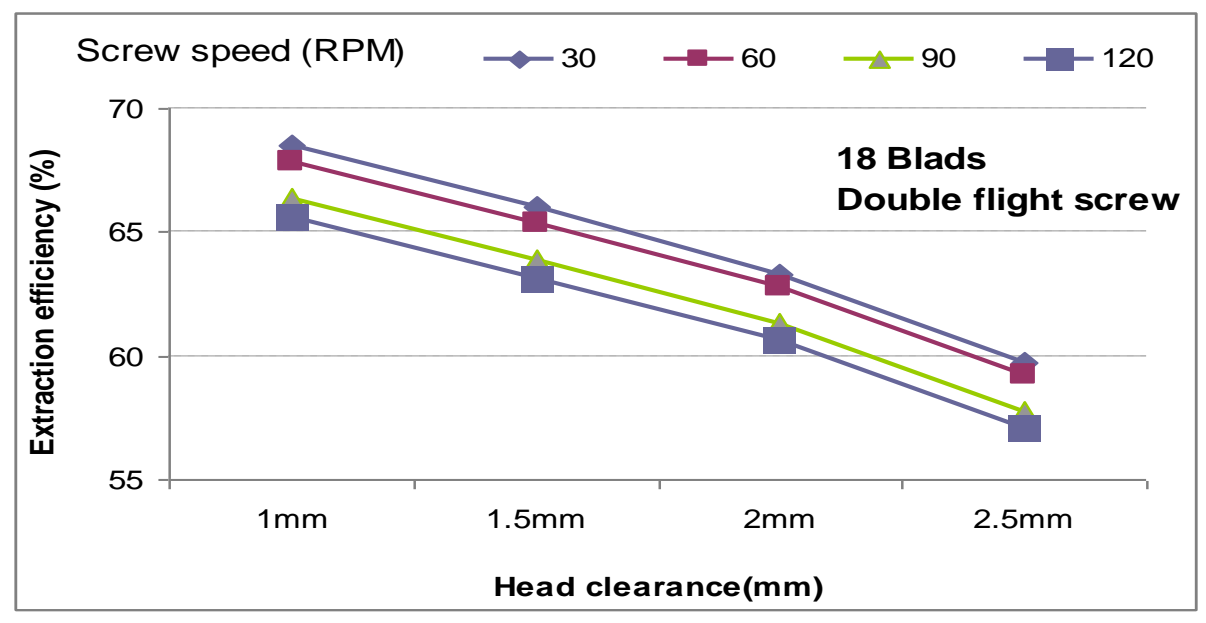

Fig(6 ): Effect of expeller screw speed, head clearance on machine extraction efficiency 


\section{4- Oil extracted percentage:}

Data in Fig.( 7 ) indicated that ,the oil extraction percentage decreased slowly by increasing the screw speed from 30 to 60,90 and $120 \mathrm{rpm}$, from 11.886 to $11.776,11.516$ and $11.376 \%$ using $1 \mathrm{~mm}$ clearance, from 11.456 to $11.346,11.086$ and $10.946 \%$ using 1.5 clearance, from 10.986 to $10.896,10.636$ and $10.516 \%$ using $2 \mathrm{~mm}$ clearance and from 10.366 to, $10.276,10.016$ and $9.896 \%$ using $2.5 \mathrm{~mm}$ clearance under 18 number of blades and double flight screw.

The decrease in oil extraction percentage by increasing the screw speed from 30 to 60,90 and $120 \mathrm{rpm}$ could be due to the decrease in seeds retention time inside the expeller barrel, that lead to increase in oil mass comes out with the cotton meal.

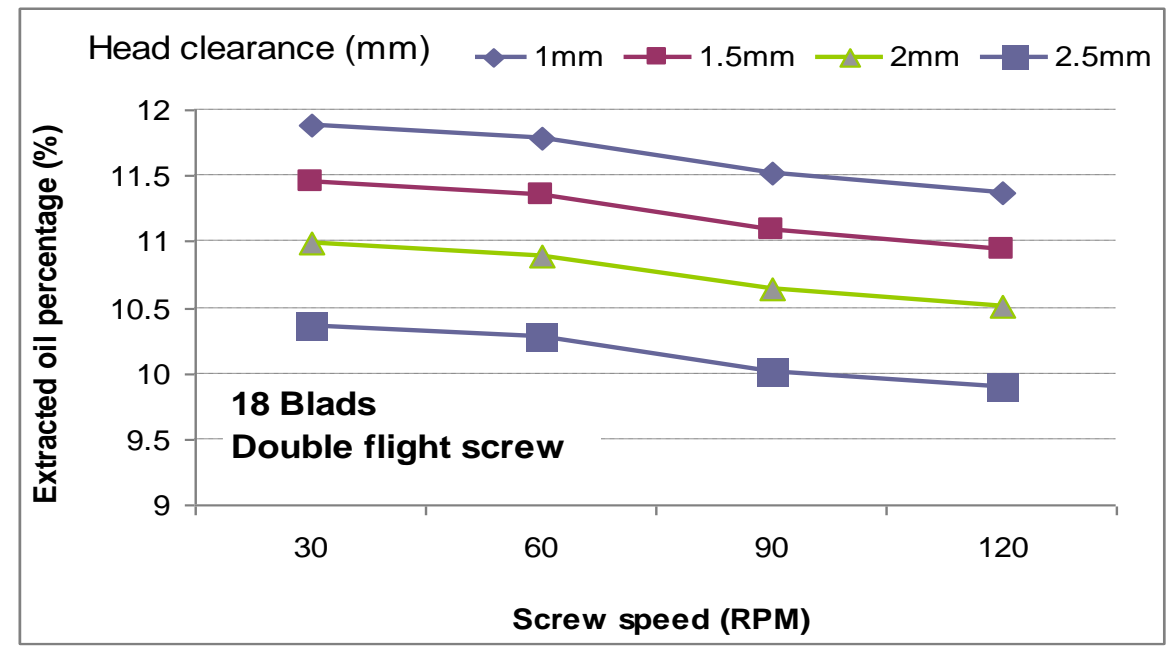

Fig(7 ): Effect of expeller screw speed, head clearance on oil extraction percentage.

Data in Fig (7) showed that, increasing the clearance between the pressing screw and machine head from 1 to 1.5 , 2and $2.5 \mathrm{~mm}$ decreased the oil extraction percentage from11.886 to $11.456,10.986$ and $10.366 \%$ at screw speed of $30 \mathrm{rpm}$., from 11.776 to $11.346,10.896$ and $10.276 \%$ at screw speed of $60 \mathrm{rpm}$, from 11.516 to $11.086,10.636$ and $10.016 \%$ at screw speed of $60 \mathrm{rpm}$ and from11.376 to $10.946,10.516$ and $9.896 \%$ at screw speed of $120 \mathrm{rpm}$. The decrease in oil extracted percentage by increasing the head clearance from 1to $1.5,2$ and $2.5 \mathrm{~mm}$ could be due to the increase in machine opening area that decease the treatment consumed time, lead to increase the oil percentage in cotton meal 


\section{5- Oil in cake percentage:}

Data in Fig. 8 ) indicated that ,the oil in cake percentage increasedby increasing the screw speed from 30 to 60,90 and $120 \mathrm{rpm}$,from 5.71 to 6.22, 6.08 and $5.82 \%$ using $1 \mathrm{~mm}$ clearance , from 6.14 to $6.25,6.51$ and $6.65 \%$ using 1.5 clearance, from 6.61 to $6.7,6.96$ and $7.08 \%$ using $2 \mathrm{~mm}$ clearance and from 7.23 to $7.32,7.58$ and $7.7 \%$ using $2.5 \mathrm{~mm}$ clearance under 18number of blades and double flight screw.

The increase in oilin cake percentage by increasing the screw speed from 30 to 60,90 and $120 \mathrm{rpm}$ could be due to the decrease in seeds retention time inside the expeller barrel, that lead to increase in oil mass comes out with the cotton meal.

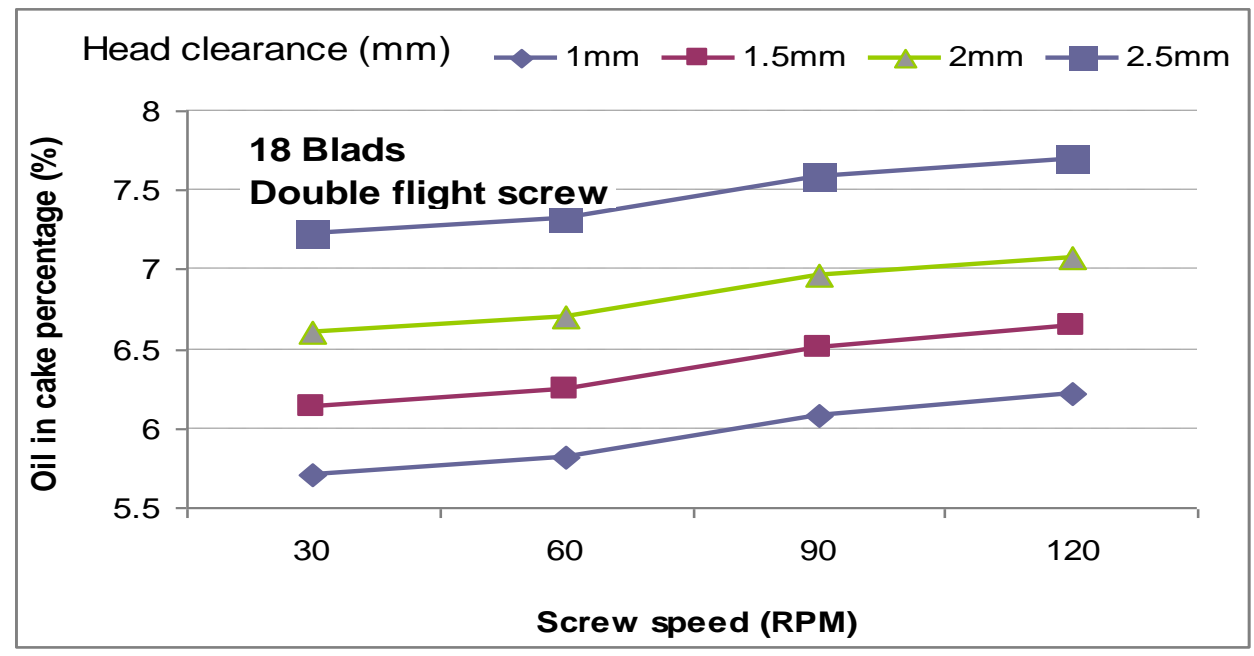

Fig(8): Effect of expeller screw speed, head clearance on oil in cake percentage.

Data in Fig (8) showed that, increasing the clearance between the pressing screw and machine head from 1 to 1.5 , 2and $2.5 \mathrm{~mm}$ increased the oil in cake percentage from5.71 to $6.14,6.61$ and $7.23 \%$ at screw speed of $30 \mathrm{rpm}$., from 5.82 to $6.25,6.7$ and $7.32 \%$ at screw speed of 60 rpm , from 6.08 to $6.51,6.96$ and $7.58 \%$ at screw speed of $60 \mathrm{rpm}$ and from 6.22 to $6.65,7.08$ and $7.7 \%$ at screw speed of $120 \mathrm{rpm}$. The increase in oil in cake percentage by increasing the head clearance from 1to $1.5,2$ and $2.5 \mathrm{~mm}$ could be due to the increase in machine opening area that decease the treatment consumed time, lead to increase the oil percentage in cotton meal 


\section{CONCLUSION}

The experimental results reveal that performance of the developed local oil press screw extraction machine was in the optimum region under the following conditions:

1- Screw speed of 60-90 rpm

2-Clearance between the screw and machine head of $1-1.5 \mathrm{~mm}$

3- Double flight screw increased the machine extraction efficiency

\section{REFERENCES}

Central Agency of Public Mobilization and Statistics( 2010) Oil Seed Production Statistics Governmental Report .

Herz, Jonathan. 1997. Using and Maintaining the Ram Press. Enterprise Works Worldwide. Washington, DC. 42 p.

Mpagalile,J.J M.A. Hanna and R. Weber(2005)Design and testing of a solarphotovoltaic operatedmulti-seeds oil press. Renewable Energy 31 (2006) 1855-1866

Oyinlola, A., A. Ojoand L.O. Adekoya(2003) Development of a laboratory model screw pressfor peanut oil expression.Journal of Food Engineering 64 (2004) 221-227.

UNIFEM (1987).United Nations Development Fund for Women. Oil Extraction. Food Cycle Tech. Source Bk, No. 1.

\section{الملخص العزبي}

تطوير وتقييم آلة محلية لعصر البذور الزيتية لرفع كفاءة الاستخلاص

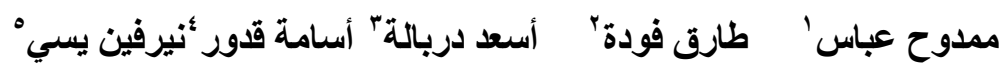

تستخدم آلات عصر الحبوب الزيتية في العديد من الصناعات الدو ائية و الغذائية وكذلك تستخدم

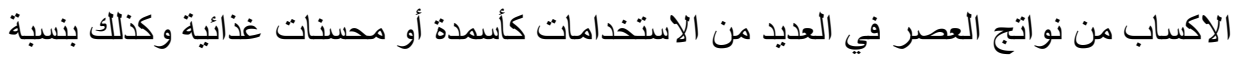

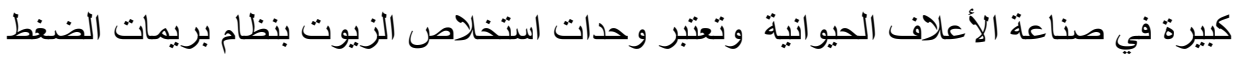

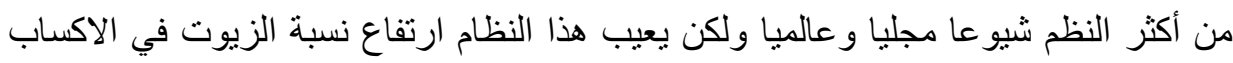

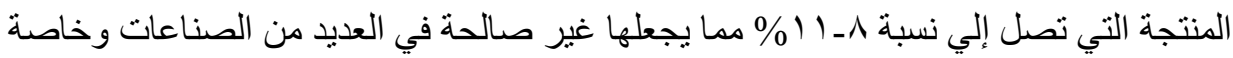

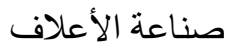

$$
\begin{aligned}
& \text { 'أستاذ الهندسة الزراعية ـ كلية الزراعة - جامعة كفر الثيخ اعليخ }
\end{aligned}
$$

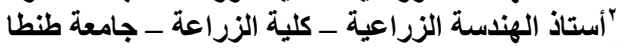

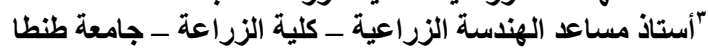

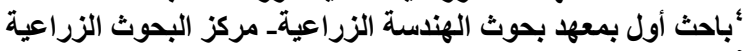

$$
\begin{aligned}
& \text { ْباحث مساعد بمعهد بحوث الاقتصاد الزراعي - مركز البحوثة البحث الزراعية }
\end{aligned}
$$


ويهدف هذا البحث إلي تطوير وتقييم اله عصر حبوب زيتية محلية الصنع لرفع كفاءة استخلاصها عن طريث تطوير نظام العصر بها من البريمات المفردة إلي البريمات المزدوجة وكذاللك زيادة مساحة سطح التلامس بين الحبوب وسكاكين العصر بزيادة عددها في محيط اسطوانة العصر الي ^ اسكينة وبالتالي زيادة عدد الجيوب بين السكاكين التي تساعد علي لئي

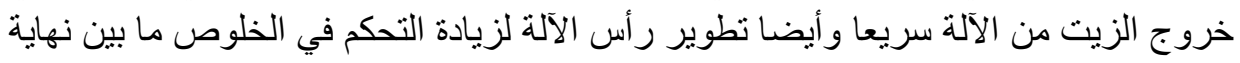

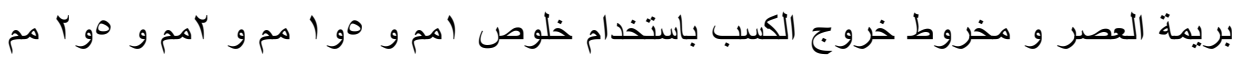
علي الترنيب وكذاللك دراسة نأثير سرعة بريمات العصر علي القياسات المختلفة باستخدام

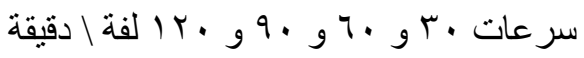
وقد أثارت النتائج أن أفضل المعاملات بعد التطوير أعطت قياسات متزنة بين الإنتاجية

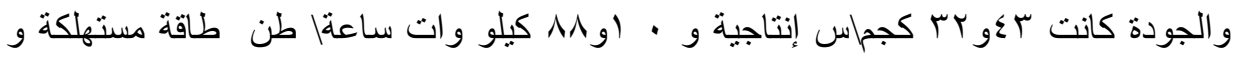

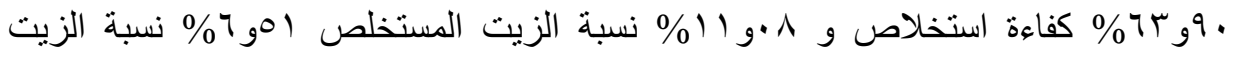

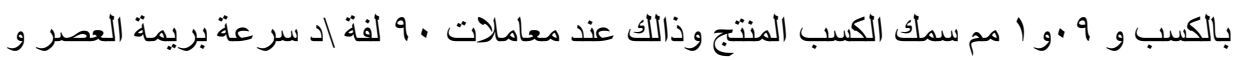
استخدام البريمة مزدوجة الخطوة و خلوص مو ا مح و عدد سكاكين 1 ( سكين 